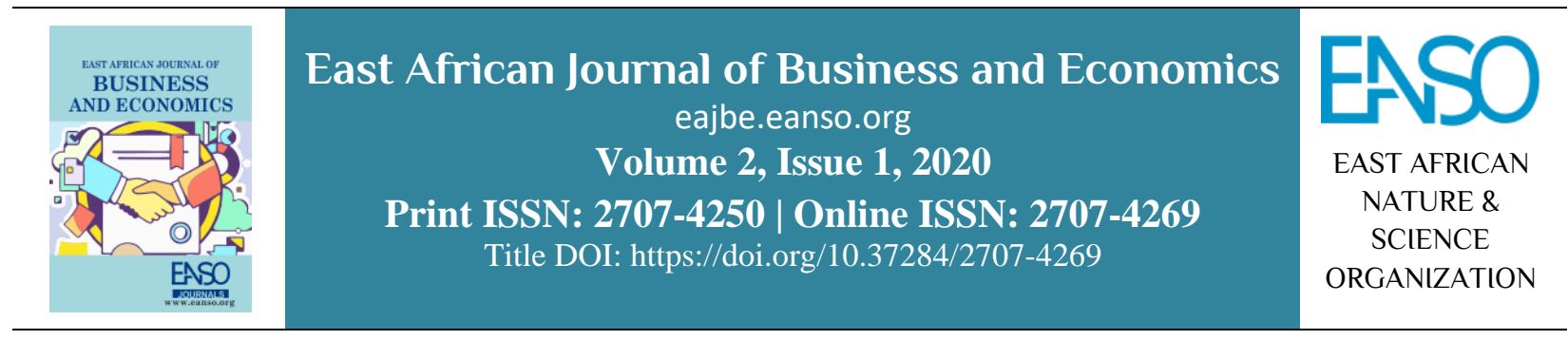

Original Article

\title{
Cost-Saving in Operational Mechanization Projects on Organizational Performance of Tea Firms
}

\author{
Carolyne Chepkemoi Kirui* \\ School of Business, Kenyatta University, P. O. Box 43844 - 00100, Nairobi, Kenya. \\ *Author for correspondence email: carolkirui38@gmail.com.
}

Article DOI: https://doi.org/10.37284/eajbe.2.1.121

\begin{abstract}
Article history:
ABSTRACT

Received: 18 Oct 2019

Accepted: 22 Nov 2020

Published: 25 Mar 2020

Cost reduction strategies assist firms to gain competitive advantages over other firms in the same industry. The introduction of mechanization in the tea

Keywords: industry has come with a shortfall of workforce reduction and the replacement of workers with machines. One of the important questions brought about by

Cost Savings, this is does mechanization benefit tea firms through cost reduction? Do the benefits outweigh the costs? This article investigates the effect of the accrued

Organization

Performance,

Strategic Analysis,

Descriptive and Causal

Design,

Tea Firms. cost savings on organization performance. Technology Acceptance Model (TAM) was used to support the concept of technology utilization in production. The descriptive and causal research design was adopted. A sample size of 101 respondents was selected from a target population of 135 respondents using stratified sampling technique from within Multinational Tea Companies in Kericho, Kenya. Data was analysed using both descriptive and inferential statistics. This study concludes that using tea-harvesting machines saves costs, which directly affects organizational performance. This study also concludes that tea-harvesting machines might affect production flexibility, which in turn influences organizational performance. There is a need to put in place policies that will enhance the use of tea harvesting machines to save operation costs. This will affect organizations' performance positively.
\end{abstract}

\section{APA CITATION}

Kirui, C. (2020). Cost-Saving in Operational Mechanization Projects on Organizational Performance of Tea Firms. East African Journal of Health and Science, 2(1), 1-9. https://doi.org/10.37284/eajbe.2.1.121

\section{CHICAGO CITATION}

Carolyne Kirui. 2020. "Cost-Saving in Operational Mechanization Projects on Organizational Performance of Tea Firms". East African Journal of Business and Economics 2 (1), 1-9. https://doi.org/10.37284/eajbe.2.1.121. 
East African Journal of Business and Economics, Volume 2, Issue 1, 2020

Article DOI: https://doi.org/10.37284/eajbe.2.1.121

HARVARD CITATION

Kirui, C. (2020) "Cost-Saving in Operational Mechanization Projects on Organizational Performance of Tea Firms", East African Journal of Business and Economics, 2(1), pp. 1-9. doi: 10.37284/eajbe.2.1.121.

\section{IEEE CITATION}

C. Kirui, "Cost-Saving in Operational Mechanization Projects on Organizational Performance of Tea Firms", EAJBE, vol. 2, no. 1, pp. 1-9, Mar. 2020.

\section{MLA CITATION}

Carolyne Kirui. "Cost-Saving in Operational Mechanization Projects on Organizational Performance of Tea Firms". East African Journal of Business and Economics, Vol. 2, no. 1, Mar. 2020, pp. 1-9, doi:10.37284/eajbe.2.1.121.

\section{INTRODUCTION}

Organizational performance in most cases is how a firm can achieve its market goals and improve organization efficiency. Several researchers have considered organizational performance using both monetary and selling criteria, including return on investment (ROI), marketplace share, the profit margin on sales, the growth of ROI, the growth of sales, the growth of market share, and overall aggressive position (Fischer, 2003). Businesses have a significant part in our lives and thus, flourishing firms represent a key component for any given country.

Continuous improvement is the centre of attention of any firm since only through performance organizations are able to grow and progress. Thus, firms' performance is one of the most vital variables in the management study and the most significant pointer of the firm performance. Even though the impression of firms' performance is common among scholars, its definition is difficult because of its many meanings (Georgopoulos \& Tannenbaum, 1997).

Internationally, advancement has proved to be a vital element for the continuous achievement of the organization. It takes care of both real and unseen resources in opposition to the flooding of the market. The outcome of the invention is based on operation mechanization, which has to be moderately on goods conclusiveness (FAO, 2006). The tea mechanization harvesting does involve both advancements in goods linked issue and eases the management cost relating to the administrative costs in a firm. This needs analyzing invention by means of a bigger scope and differentiating between the equipment and managerial related invention (Lach \& Schankerman, 2008). The role of operation mechanization is to add the effectiveness of the invention procedures. The information pertaining to innovation performance needs to be communicated and compared with invention and purpose objective (Davil, Epstein, Mark, Shelton, \& Robert, 2006) so as to check whether it meets the expectations of the improving organization performance.

Operation mechanization is mostly embraced in Sub-Saharan Africa by local community leaders, politicians and large-scale farmers. The renewal of its use as a key factor of farming progress programmes will in most cases be as controversial as possible (Botswana, In, \& Mrema, 2011). Though Africa is mainly considered as having a land surplus with reasonably small residents populations in the majority of the nation, earnings stay behind and most factors which were directing operation mechanization in some other nations (Binswanger, 2006) might not be available in many different countries in Sub-Saharan nations. As much as this is the case, African interaction with mechanization has generally not been successful as such (Eicher and Baker, 1982; Pingali, 2007). In general, there is a risk that absence of operation mechanization strategy and policies currently might worsen the field and agricultural level situation while previous mistakes of innovating in government operation mechanization assist and furnish schemes are recurring.

With innovative goods, too numerous determinants which emerge too rapidly for the unaware to respond to with comprehensive manufactured goods conceptualization, inventors can repeatedly appraise the improbability of their hard work at least qualitatively and make a wise and informed decision on whether to withdraw the effort or change to another which is much more reasonable market (Cynthia 2004). 
A number of scholars think about consumer point of reference as significant as contest focus and inter-functional harmonization (Narver \& Slater, 2010), others think about it the most basic characteristic of company way of life (Deshpande, Farley, \& Webster, 2003) established a constructive association among clients orientation and inventive firms, but they do not make the difference of whether the organization are inventive in technological or managerial aspects. Organizations devoted to greater client significance comprise to be inventive all through their entire company system as contrasting to exclusively in goods or services (Parsons, 2011).

Mechanized harvesting may offer quick and improved picker output and thus may decrease the price of harvesting. Majority of tea producing nations have embraced mechanized tea plucking as a set put into practice and these include; Japan, Malaysia, Russia, China, India, Turkey and Argentina (Bore, 2009). Mechanical plucking in Kenya has been attempted on test foundation in the 1980s' to-date and is now being adopted in the estate sub-sector on an important scale. However, wrong plucking principles may lead to excellence decline in inexperienced leaf, and eventually in the manufactured tea (Burgess, 2006). In Kenya, the mechanization of tea harvesting in multinational tea company has been adopted although it has been dogged by controversy. Further, the use of tea mechanization in Multinational tea firms in Kericho County has taken root and almost all the tea companies have adopted its use. That is why this study is important in addressing the effect of operational mechanization on organization performance.

Tea exports are the second foreign exchange earner contributing about $26 \%$ of the total exchange earnings for Kenya and supporting livelihoods of more than 3 million persons directly and indirectly. Kenya is among the largest tea producers in the world. Kenya together with Sri Lanka and India produces over 50 per cent of tea consumed globally.

Currently, the tea industry has been undergoing tough times especially due to the global drop in tea prices. Due to this, the tea industries have been trying their best to reduce any cost, which reduces the profits. Majority of the people employed in tea estates are the tea pickers. These tea pickers apart from creating a huge wage bill are also entitled to allowances such as medical cover, NSSF and other benefits. This has overburdened an already burdened tea sector. With the advent of operational mechanization, the multinational tea companies have adopted the use of tea harvesting machine. The tea harvesting technology has been received with many concerns such as the quality of tea leaves, creation of unemployment and increasing the number of idlers in both the village and the urban areas who are a threat to the security of the community.

Further, the cost of plucking tea has greatly increased within the past few years and it has significantly reduced the grower's earnings. In order to lower the cost of plucking, there has been an attempt to use other alternative methods such as mechanical harvesting machines. The main advantage of replacing hand plucking of tea with the machine is the increase in volumes and speed of harvesting the product. Currently, the cost of plucking ranges between Kshs 2.50 to 3.47 per kg of green leaf in machine plucking compared to Kshs 10 to 12 per $\mathrm{kg}$ of green leaf in hand plucking, according to the collective bargaining agreement between the multinational tea companies and the Kenya plantations and agricultural workers' union (KPAWU), 2012. There is a big gap between the costs of these two plucking technologies (Bore, 2009).

The effect of operational mechanization on organization performance has attracted limited research especially in the area of study. Thus, there was a need to assess this aspect with specific reference to Tea Firms in Kericho County. The main aim of the paper is to determine the effect of cost savings on organization performance

\section{LITERATURE REVIEW}

\section{Theoretical Review on Technology Acceptance Model (TAM)}

The study anchored on Technology Acceptance Model (TAM). This is an information systems approach which tells how users recognize and utilize technology. The theory suggests when users are introduced to a new technology there will be a 
number of determinants which will affect their choice on ways how and the time they used it, mainly: Perceived usefulness (PU) which is the extent into which an individual believes that utilizing a given technology will improve his or her job work. Perceived ease-of-use (PEOU) is an extent in which any anyone perceived that using a given technology will be free from effort (Davis, 1989).

A number of scholars have repeated Davis's original study (Davis, 1989) to give scientific relationships existing between worth, simplicity of use and system use (Adams, 1992) More attention has put on examining the strength and soundness of the survey instrument used by Davis. Adams et al (Adams, 1992) replicated the work of Davis (Davis, 1989) to demonstrate the validity and reliability of his instrument and his measurement scales. They also extended it to diverse situations and, using two diverse samples, they established the internal stability and replication reliability of the two balance. Hendrickson, Massey, \& Cronan (1993) on their part found far above the ground consistency and excellent test-retest reliability. (Stuart, 2000) (Szajna, 1994)on his part noted that the apparatus had prognostic soundness for the intention to utilize, self-reported usage and mind-set toward use. This study concluded and established the validity of the Davis tool, to assist its use with diverse populations of users and diverse software choices.

Venkatesh and Davis expanded the original TAM theory to clarify the perceived value and practice intentions in terms of community influence and cognitive instrumental processes. They expanded model, referred to as TAM2, was measured in both voluntary and compulsory settings. This outcome powerfully supported TAM2 (Venkatesh, 2000). In trying to bring together the main opposing user acceptance models, Venkatesh et al. formulated the Unified Theory of Acceptance and Use of Technology (UTAUT). The model found out that it could outperform each of the individual models (Venkatesh et al 2000). Independent of TAM, (Scherer, 1985) developed the Matching Person \& Technology Model in 1986. The MPT Model has supplementary evaluation procedures used in technology assortment and decision-making, as well as outcomes study on differences among technology users, non-users, avoiders, and unwilling users.

\section{Literature on Cost-Saving of Mechanized Tea harvesting and Organization Performance}

Due to the shortage of labour and high labour costs in 1970s tea companies in Argentina introduced mechanized tea harvesting system. African nations like Zimbabwe and South Africa also adopted tea harvesting methods later on. Shear harvesting was first used as an alternative to hand plucking and it started to be used in Japan (Wilkie \& Malenga, 1993)Mechanical plucking also include motordriven machines which starts from handheld machines to tractor mounted harvesters like ride-on machines. These harvesting machines require good ground conditions and evenly growing tea shoots and trained canopies for better performance.

Thus, the use of machines is greatly limited by field conditions and pattern of shoot growth. Mechanical plucking is one effective way to increase the productivity of labour, in addition, to stabilize labour deployment and bring more leaves to the plucking basket. Work done on mechanical plucking at Tocklai for the past years showed an increase in productivity (Barbora, Jain, \& Rahman, 1984). Though mechanized tea harvesting is quicker and cheaper, the product quality and its value are low (Bore, 2009). The process increases the speed of plucking and decreases the personnel involved. The main merit of mechanical plucking includes high effectiveness, low labour cost, redeeming time and consistent plucking table. Further, it has also challenges which include a decline in tea leaves quality, inability to use in high sloppy land, and hardship in repairing and maintaining of the machines.

The tea harvesting method has also influence product and tea leaves quality, the technique of harvest in most cases affects the kind and number of shoots that remain on the bush after harvesting. When immature tea leaves are plucked this means that the next harvesting will be affected. The tea quality could be assessed at the different process first at the factory gate as soon as it is offloaded from the field, during processing and after processing by sensory characteristics (Burgess, 2006). 
Depending on the range of harvesting machine, the load of the machine may be different from about 10 $\mathrm{kg}$ to several tones. These tea harvesting machines are manufactured to adopt the varying conditions of the field and pattern of shoot growth. Though there are many kinds of mechanized harvesters, their common characteristic is that it does not select the shoots to be harvested (Wijeratne, 2003). The work done by the tea harvesting machines mainly depends on the length of blades (harvesting section), the longer blades give an upper output than shorter ones. Further, the output of the machines also varies with the yield potential and the landscape (mainly slope) of the tea land (Wijeratne, 2003).

Tea mechanization harvesting is non-selective in the sense that it harvests everything within its reach. The machine operators can hold the machine below the plucking table and this will result in harvesting immature shoots which are not supposed to be harvested in that round but in the next round. This means that in the next plucking round there might be low leaves to be harvested hence the next harvest yield decline. When tea mechanization is used only during peak cropping months, the loss of yield can be minimized to about 20-30\% (Wijeratne, 2003). In most cases, the tea harvesting machine leads to poor quality crops in comparison to manual harvesting. In most cases also crop harvested by machines consists of poor-quality shoots like over mature (coarse) leaves and stems, and undeveloped shoots (Wijeratne, 2003). The over full-grown shoots will influence the end product. It is hard to process them in the factory so the end product quality will be highly reduced.

Maina and Kaluli (2009), evaluate the practicality of mechanical and hand harvesting of tea in Kenya. The researcher used NPV to assess the capability of these two harvesting methods. The researchers found that using mechanical harvesting method is much cheaper and decreases costs and has a high yield compared to manual harvesting method. NPV of machine-harvested tea was as double as much as the NPV of manually picked tea. This indicates that automatic harvesting method was more viable than manual harvesting method. The researchers only used net present value to review the practicality of harvesting methods; they were supposed to use diverse methods so as to make a good conclusion.
By 2006, the area under tea harvesting mechanization, in Kericho District, comprised of 694 hectares. The main tea processors include James Finlay Ltd which has already mechanized about 600 hectares' tea harvesting. Unilever Tea Kenya Ltd on its part has 54 hectares of tea with mechanized harvesting while Sotik tea 40 hectares (Bore, 2009). The area under mechanized harvesting is approximately $2.3 \%$ of the area under tea. The adoption of mechanized tea harvesting is on the rise with large companies using machines in most of their tea estates. Various types of machines have been developed from handheld single man machines, through rickshaw machines pulled by two operators to large self-propelled harvesters. The success of machines has varied as much as the design of the machines themselves. Tea companies require information on how to manage tea bush under mechanical harvesting including practices such as plucking rounds, table height rise and pruning cycles (Nyasulu, 2009).

Manual machines are used by several large scale companies which are either operated by one or two operators. These are mainly adopted to be used in hilly terrain where wheeled harvesters cannot be used. A frequent complaint about this type of machine, however, is that it is difficult to maintain a good table with it because operators tend to carry the machine at a convenient height rather than at the required table height. When carried too low, the maintenance leaf is plucked, thereby reducing the tea quality (Obanda \& Owour, 2012).

\section{METHODOLOGY}

Descriptive design and causal research design were employed in this study. The total target population for the study was 135 respondents and a sample size of 101 respondents was given questionnaires to fill selected using stratified random sampling from Multinational tea firms in Kericho county. The study used descriptive statistics analyse data. While charts and frequency table were used for data presentations. 


\section{RESULTS AND DISCUSSION}

\section{Mechanization in Tea Harvesting}

Mechanization of tea has been introduced in numerous areas in manufacturing of tea from harvesting, ploughing, fertilizer application, spraying, weighing and transporting to the manufacturing industry. The results revealed that about $60(59.41 \%)$ of the respondents had their farms which ranged from $26 \%$ to $50 \%$ under mechanized harvesting, whereas $41(40.59 \%)$ had farms over $51 \%$ under mechanized harvesting. From the data obtained from the respondents, an area ranging from $10 \%$ to $25 \%$ of tea farms were not under mechanized harvesting. These results seemed to imply that at least a higher percentage of tea farms are under mechanized harvesting.

\section{Cost Savings and Organization Performance}

The paper aims at determining the effect of cost savings on organization performance. To achieve this objective, managers and supervisors in tea firms in Kericho County were asked to react to several statements intended to describe cost saving of mechanized tea harvesting in the tea industry. Costs saving was defined in terms of a decrease in direct labour numbers, increased productivity (Harvest per person), reduced man-hours in the field, reduced field supervision costs and a decrease in employee welfare costs. The status of cost-saving was rated as per the level of agreement in the following terms: strongly disagree, disagree, neutral, agree and strongly agree.

Table 1: Mechanization Cost Saving and Organization Performance

\begin{tabular}{|c|c|c|c|c|c|c|}
\hline Questions & 5(SA) & 4(A) & $3(\mathrm{U})$ & 2 (D) & 1 (SD) & Mean \\
\hline $\begin{array}{l}\text { Mechanization decreases } \\
\text { direct labour reducing cost } \\
\text { savings }\end{array}$ & $91(90.1 \%)$ & $0(0.0 \%)$ & $0(0.0 \%)$ & $10(9.9 \%)$ & $0(0.0 \%)$ & 4.703 \\
\hline $\begin{array}{l}\text { Mechanization increased } \\
\text { productivity- harvest per } \\
\text { person }\end{array}$ & $66(65.3 \%)$ & $35(34.7 \%)$ & $0(0.0 \%)$ & $0(0.0 \%)$ & $0(0.0 \%)$ & 4.653 \\
\hline $\begin{array}{l}\text { Mechanization reduce man- } \\
\text { power hours in the field }\end{array}$ & $\begin{array}{l}66(65.3 .6 \\
\%)\end{array}$ & $35(34.7 \%)$ & $0(0.0 \%)$ & $0(0.0 \%)$ & $0(0.0 \%)$ & 4.653 \\
\hline $\begin{array}{l}\text { Mechanization reduce field } \\
\text { supervision cost }\end{array}$ & $48(47.5 \%)$ & $43(42.6 \%)$ & $10(9.9 \%)$ & $0(0.0 \%)$ & $0(0.0 \%)$ & 4.376 \\
\hline $\begin{array}{l}\text { Mechanization decreased in } \\
\text { employee welfare costs }\end{array}$ & $54(53.5 \%)$ & $47(46.5 \%)$ & $0(0.0 \%)$ & $0(0.0 \%)$ & $0(0.0 \%)$ & 4.535 \\
\hline
\end{tabular}

Table 1 above indicates that $91(90.1 \%)$ strongly agree that decrease in direct labour numbers would result to cost-saving, while $10(9.9 \%)$ of the respondents disagree to the fact that decrease in direct labour numbers would result in cost saving. From the data obtained there were no response on strongly disagree, neutral and agree. Hence mechanization has enabled the organization to decreased direct labour (mean of 4.703).

The results indicated $66(65.3 \%)$ strongly agree and $35(34.7 \%)$ of the respondents agree to the fact that increased productivity - harvest per person results in cost-saving as results of mechanization. From the data obtained there were no response on strongly disagree, disagree and neutral. Mechanization increased productivity harvest per person (mean of 4.653).

The results indicate that $66(65.3 \%)$ strongly agree and $35(34.7 \%)$ of the respondents agree to the fact that increased productivity - harvest per person results in cost-saving due to mechanization. From the data obtained there were no response on strongly disagree, disagree and neutral. Mechanization increased productivity through harvest per person saving cost (mean of 4.653).

The results showed that 48 (47.5\%) strongly agree, $43(42.5 \%)$ of the respondents agree and neutral were $10(9.9 \%)$ that mechanization reduces field supervision cost hence saving cost. From the data 
obtained there were no response on strongly disagree and disagree. The reducing field supervision cost results to cost reduction (mean of 4.653).

About 54 (53.5\%) strongly agree and 47 (46.5\%) of the respondents agree to the fact that a decrease in employee welfare cost results to cost-saving. From the data obtained there were no response on strongly disagree, disagree and neutral. The results indicated that mechanization decreased employee welfare costs (mean of 4.535). Therefore, the results above on cost-saving shows that there is a strong relationship between cost-saving and organization performance.

\section{DISCUSSION OF RESULTS}

According to this study, the results indicate that $90 \%$ of the respondents agree that decrease in direct labour numbers would result to cost-saving, while $10(9.9 \%)$ of the respondents disagree to the fact under study. The study found that the respondents indicate that $65 \%$ strongly agree that increased productivity - harvest per person would result to cost-saving and $35(34.7 \%)$ of the respondents agree to the fact that increased productivity harvest per person results to cost-saving. According to the study, $91 \%$ of the respondents strongly agreed that reduced field supervision cost would result in cost saving. The finding of this study found out that $54 \%$ of the respondents strongly agree that a decrease in employee welfare cost would result in cost-saving and $47 \%$ of the respondents agree to this fact under study.

\section{CONCLUSIONS}

The study was based on one theory that is the Technology Acceptance Model (TAM). The study utilized mainly Technology Acceptance Model due to its relevance to the study. Technology Acceptance Model (TAM), an information systems theory that models how users come to embrace and utilize technology. This approach noted that people who are supposed to utilize technology are offered with new technology, then there are several determinants which might influence their decision on how and when they used it especially its usefulness to the organization and work processes.
According to this study majority of the respondents agree that decrease in direct labour numbers would result to cost-saving, that it will increase productivity - harvest per person would result to cost-saving and that reduced field supervision cost would result in cost-saving and that it will cause a decrease in employee welfare cost would result to cost-saving. This supports what this theory advocates for that is, technology will be implemented if it is useful. This study concludes that using tea harvesting machine saves costs which intern affects organization performance.

\section{RECOMMENDATIONS}

In relation to the conclusions above, the study gives the following recommendations relating to policies programs and future research regarding the effect of operational mechanization on organization performance of Tea Firms. This study, therefore, recommends that agricultural stakeholders should integrate the use of mechanization in their programs to ensure that they do their work effectively.

The respondents in this study noted that through the use of tea harvesting machines decrease in direct labour numbers would result in cost-saving, increased productivity - harvest per person would result in cost-saving. It would also reduce field supervision cost resulting in cost-saving as well as it would decrease employee welfare cost. Therefore, there is a need to put into place policies which will enhance the use of tea harvesting machines so as to save the cost and thus affects the organization performance positively. 


\section{REFERENCES}

Adams, R. (1992). Work Themes, Issues and Critical Debate. London: Macmillan Press.

Barbora, B., Jain, N., \& Rahman, F. (1984). Effect of different methods of training young tea, Camellia sinensis L. 0. Kuntze on the bush frame. Journal of Plantation Crops, 12(1), 6474.

Binswanger, H. (2006). Agricultural mechanization: a comparative historical perspective.

Bore, J. K. (2009). Mechanical harvesting of tea in Kenya, A review and future prospects. Nairobi. Kenya.

Botswana, In, G., \& Mrema, e. (2011). Agricultural Mechanization Policies. A review of developments of agricultural Mechanization, $\mathrm{p}$. 43-58.

Burgess. (2006). Evaluation of simple hand-held mechanical systems for harvesting tea. Experimental Agriculture, 42: 165-187.

Davil, T., Epstein, Mark, J., Shelton, \& Robert. (2006). "Making Innovation Work: How to manage it, Measure It, and Profit from it., pp 31- 40 .

Davis, F. D. (1989). "Perceived Usefulness, Perceived Ease of Use and User Acceptance of Information Technology". MIS Quarterly 13 (3), 319-339.

Deshpande, R., Farley, J., \& Webster, J. F. (2003). "Corporate culture, customer orientation, and innovativeness in Japanese firms: a quadratic analysis.". Journal of Marketing 57 (1), 23-37.

Eicher, C. K., \& Baker, D. C. (1982). Research on agricultural development in Sub-Saharan Africa: A critical survey (No. 54071). Michigan State University, Department of Agricultural, Food, and Resource Economics.

FAO. (2006). Farm power and mechanization for small farms in sub-Saharan Africa, by B.G. Sims \& J. Kienzle, Agricultural and food engineering technical report No.3. Rome: Agricultural Support Systems Division.

Fischer, K. (2003). Fischer, K. (2003). A framework for quality management research and associated measurement instrument. Journal of Operations Management, 11, 339366.

Georgopoulos, B., \& Tannenbaum, A. (1997). "A Study of Organizational Effectiveness", American Sociological Review, 22, pp. 534-40.

Hendrickson, A., Massey, P. D., \& Cronan, T. P. (1993). On the test-retest reliability of perceived usefulness and perceived ease of use scales. MIS Quarterly, 17(2) 227-230.

Kaluli, W., \& Maina, J. (2017). Assessment of mechanical harvesting of tea and its viability for use in Kenya.

Kenya, T. B. (2009). Fact Sheet on Kenya Tea. Nairobi: TBK.

Lach, S., \& Schankerman, M. (2008). Incentives and invention in universities. The RAND Journal of Economics, 39(2), 403-433.

Narver, J. C., \& Slater, S. (2010). "The effect of a market orientation on business profitability.". Journal of Marketing, 54(4): 20-35.

Nyasulu, S. (2009). Mechanical harvesting of tea. $A$ research review,Newsletter.No.14,6, 3-1.

Obanda, P., \& Owour, G. (2012). .(2012). Gross margin analysis of Amaranth vegetables production. Economics of Innovation and New Technology (8). Journals of agriculture and biodiversity research voll. of empirical studies, 5-25.

Parsons, G. (2011). Information technology: a new competitive weapon, Sloan Management Review 25, 1 4-14. 30.

Pingali, P. (2007). Agricultural mechanization: adoption patterns and economic impact. Handbook of agricultural economics, 3, 27792805. 
Porter, M., \& Miller, V. (1985). How information gives you competitive advantage. Harvard Business Review, Vol.63, pp.149-160.

Scherer, D. E. (1985). Intention, perceived control, and weight loss: An application of the theory of planned behaviour. J. Personality and Soc. Psych 49(3), 843.

Shelton, J., Carthy, Robert, J., Minichiello, \& Joseph. (2006). (2006), "Business Policy and Strategy". India: New Delhi.

Stuart, W. (2000). Influence of sources of communication, user characteristics and innovation characteristics on adoption of communication technology (Doctoral dissertation. Pro Quest Digital Dissertations. The University of Kansas.

Szajna, B. (1994). Software evaluation and choice: Predictive validation of the technology acceptance instrument. MIS Quart. 18(3), 319324.

Venkatesh, V. (2000). Determinants of perceived ease of use: Integrating control, intrinsic motivation, and emotion into the technology acceptance model. Information Systems Research, 11, 342-365.

Wijeratne, M. A. (2003). Harvesting policies of tea (Camellia sinensis L.) for higher productivity and quality. Tropical Agricultural Research and Extension, 6(14), 91-97.

Wilkie, A., \& Malenga, N. (1993). Shear plucking in Southern Africa, a review of technical aspects proceedings of the first regional seminar, Blantyre, TRF (CA) World Bank Research Observer, 187-211,1(1): 27-56. 